\title{
Influence of Climatic Parameters on Changes in the Density and Viscosity of Diluted Bitumen after a Spill
}

\author{
Thomas King1,*, Patrick Toole ${ }^{1}$, Brian Robinson ${ }^{1}$, Scott Ryan ${ }^{1}$, Kenneth Lee ${ }^{1}$, Michel Boufadel ${ }^{2}$, Haoshuai Li \\ Jason Clyburne ${ }^{4}$
}

${ }^{1}$ Department of Fisheries and Ocean Canada, Bedford Institute of Oceanography, Dartmouth, Nova Scotia, B2Y 4A2, Canada.

${ }^{2}$ Center for Natural Resources Development and Protection, Department of Civil and Environmental Engineering, New Jersey Institute of Technology,

Newark, 07102, New Jersey, USA.

${ }^{3}$ Key Laboratory of Marine Chemistry Theory and Technology, Ministry of Education, Ocean University of China, Qingdao 266100, China.

${ }^{4}$ Atlantic Centre for Green Chemistry, Departments of Chemistry and Environmental Science, Saint Mary's University, Halifax, NS, B3H 3C3, Canada.

\section{A R T I C L E D E T A I LS}

\section{Article history:}

Received 31 August 2019

Accepted 12 September 2019

Available online 14 October 2019

\section{Keywords:}

Dilbit

Dilsynbit

Synbit

Oil Weathering

Climatic Parameters

\begin{abstract}
A B S T R A C T
Nonconventional oil products (Access Western Blend [dilbit], Western Canadian Select [dilsynbit], and Synthetic Bitumen [synbit]) and a conventional crude (Heidrun) were naturally weathered on sea water under spring (April-May) and summer (July-August) conditions to improve our understanding of the effects of climatic parameters (air and water temperature, wind speed, and light intensity [solar radiation]) on their density and viscosity. The physical properties data, from each experiment, was fitted to a previously developed hyperbolic function that captured different rates of changes in densities and viscosities of the oils due to preferential weathering of the diluent portion of the diluted bitumen products. A combination of multiple correlation and regression analysis of experimental data over two seasons revealed that there were significant $(\mathrm{p}<0.05)$ trends among the measured climatic parameters and the changes in the densities and viscosities of oils after a spill. Analysis of variance (repeated measures) showed that seasonal conditions had a significant $(p<0.01)$ effect on the changes in the physical properties of all oils after release. These results on key factors which control the rates of natural attenuation for nonconventional oils spilled on water will aid decision making during oil spill preparedness and response operations.
\end{abstract}

\section{Introduction}

Crude oil continues to play a critical role in meeting global energy demands. Oil exploration and production will persist until alternative energy sources reduce our dependence on fossil fuels. Canada holds an estimated 168 billion barrels of oil in reserves and produces around four million barrels/day (b/d) of oil, of which it consumes around $0.7 \mathrm{~b} / \mathrm{d}$ and most ( 3.3 million $b / d$ ) of the surplus is transported to the USA [1]. Heavy crude oil represents approximately half of the oil produced by Canada [2] and currently there are several pipelines located in western Canada that transport heavy oil products to market. These pipelines are located both onshore near aquatic areas and close to marine ports where oil products are eventually shipped by tanker to global markets. Although spills from tankers have significantly decreased over the past decade [3], they remain of major concern in Canada since ship traffic is anticipated to increase significantly as production of heavy oil from the Alberta Oil Sands increases. Major oil spills can have devastating economic, social and environmental impacts on affected communities. Spills of heavy oil products (bitumen blends) are a controversial issue, since there is limited literature available on the fate and behaviour of spills of these products in diverse environments to support the preparation of comprehensive response plans [4].

Currently there are many oil spill cleanup options available, including containment and skimming, in situ burning, the application of shoreline cleaning agents, bioremediation [5], and natural attenuation. In Canada, oil spills near coastal areas are primarily recovered through mechanical means, such as containment and skimming, and/or left to natural attenuation. Viscosity is an important factor to consider when recovering oil with skimmers and transferring it with pumps. There is concern over long-term damage to aquatic areas, as the recovery of highly viscous oil is

limited without the availability of highly specialized equipment. Density is also important during oil spill response planning as it determines whether the oil will ultimately sink or float, especially when spilled in fresh water, as fresh diluted bitumen products are less dense than sea water. Subsurface oil within the water column and sunken oil entrained within sediments is challenging to track, monitor, and effectively treat with traditional oil spill response options that are typically designed for use at the water surface. Enhancing knowledge of the rates of changes in these two physical properties will aid in assessing the fate of spills of diluted bitumen in aquatic areas and decision-making during response operations.

When oil is spilled in the environment, numerous physical, chemical and biological processes reduce, eliminate, or transform the chemicals associated with the oil. Collectively these processes are referred to as weathering. Chemical and physical processes account for a portion of the oil degradation and include evaporation, dissolution, dispersion, photochemical oxidation and sedimentation that involves oil sinking to the bottom after attaching with sediment particles to form oil particle aggregates, OPAs [6,7]. The most important of these physical processes affecting oil spills on the water surface is evaporation [8], which occurs in the first few days after a spill and accounts for a 5 to $75 \%$ loss of the mass of the spilled oil, depending on the oil type and environmental conditions [9]. The chemical process of photo-oxidation has emerged to be an equally important process to evaporation; a recent lab study has shown that exposure of oil to solar radiation can cause photo-chemical weathering of oil, causing significant changes in the chemical composition of light crude oil within a few days [10]. In addition, based on photo-oxidation of oil under ultraviolet irradiation conducted in the lab, Appeli et al. [11] reported that the partial photo-oxidation of oil on the water surface led to $50 \%$ of the weathered saturates and aromatics being transformed to oxygenated hydrocarbons within 10 days during the Deepwater Horizon oil spill. The eventual fate (months to years) of the remaining oil is influenced by biological processes involving microorganisms (e.g. heterotrophic bacteria and fungi) and is considered critical in the remediation of the non-volatile, water insoluble fraction of crude oil if 
ecological conditions are favorable [12]. A recent study provided a model to capture and predict changes in densities and viscosities of various diluted bitumen products when they are weathered in temperate waters [13]. The model could be directly applied to oil spills in the environment, provided they have the same general conditions adopted in the model.

Subsequent to the arguments above, as climate change continues on a world-wide basis, the climate in which a spill occurs play an important role in the weathering of an oil after a spill. The aim of this study is to investigate climatic parameters (rainfall, air and water temperature, wind speed, and light intensity [solar radiation]) that could potentially influence natural changes in the physical properties (density and viscosity) of oil weathered on water during spring (April-May) and summer (July-August) conditions. Also, to determine if the season, in which the spill occurred, could affect the rates of changes in the physical properties of oil after release. To simulate a range of these conditions, we conducted oil weathering experiments in an outdoor circular flume tank located at the Bedford Institute of Oceanography, Dartmouth, NS, Canada. Three diluted bitumen products were selected for the weathering study, which represent the bulk of nonconventional oils that are transported throughout North America [14]. In addition, a conventional crude was selected to compare its rate of weathering to the nonconventional oils, because its physical properties (density and viscosity) are relatively close to those of the fresh diluted bitumen products.

\section{Experimental Methods}

\subsection{Oil Products}

Four products were used in the weathering study; Access Western Blend (AWB, dilbit), a mixture of $30 \%$ condensate with crude bitumen; Western Canadian Select (WCS, dilsynbit), a mixture of $50 \%$ condensate/synthetic crude/light crude oil blended with crude bitumen; Synthetic bitumen (synbit), 50\% synthetic crude mixed with crude bitumen and a Norwegian conventional medium crude, Heidrun.

\subsection{Circular Flume Tank}

The circular flume tank is located at the Bedford Institute of Oceanography, Dartmouth, Nova Scotia, Canada. It was fabricated from fiberglass and measures 1.0 meter $(\mathrm{m})$ in height $\mathrm{x} 1.5 \mathrm{~m}$ in diameter and $4.7 \mathrm{~m}$ in circumference (Fig.1). Further details on the tank are reported by King et al., [13].

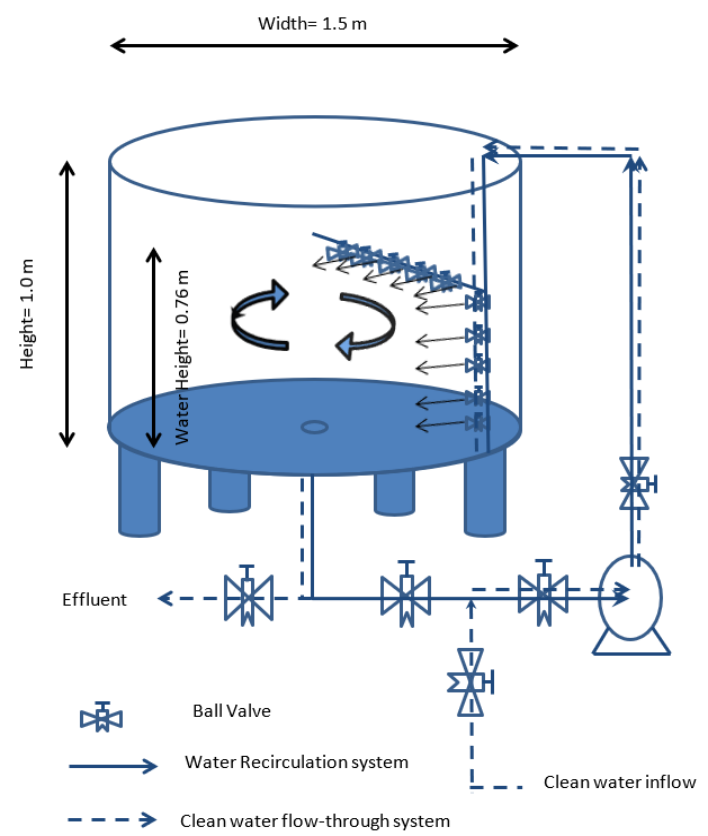

Fig. 1 Schematic of the circular flume tank (not drawn to scale)

Natural sea water for the experiments was taken directly from the Bedford Basin, Nova Scotia (NS) and filtered through a $5 \mu \mathrm{m}$ filter (filter sock; Atlantic Purifications Systems Inc., NS, Canada) into the flume tank. The tank was filled with water to a depth of $0.76 \mathrm{~m}$, which results in a water volume of $1.31 \mathrm{~m}^{3}$ (1310 litres). The inlet of the circulating pump $(3 / 4$ HP ReeFlo single phase, 1725 RPM, 115 VAC) was connected to a submerged manifold. The manifold was a vertical and horizontal injection system constructed of $0.038 \mathrm{~m}$ polyvinylchloride (PVC) pipe with evenly spaced $0.013 \mathrm{~m}$ spigots and ball valves to control water flow. Water was https://doi.org/10.30799/jespr.176.19050305 pumped out through a $0.051 \mathrm{~m}$ ID pipe made of Schedule $40 \mathrm{PVC}$. The test was set up to produce a rotational water current flow, within the tank, in a clock-wise direction. The velocity was designed to be uniform with depth to reduce flow short-circuiting, especially at the tank bottom. Water currents were produced at an average speed of $20.7 \pm 0.4 \mathrm{~cm} / \mathrm{s}$ on the surface of water in the flume tank.

\subsection{Floating Microcosm}

In order to keep the oils floating on the water surface and in contact with the water column, a floating microcosm system was adopted (Fig. 2) [13]. It consisted of a circular disk of diameter $0.51 \mathrm{~m}$ made out of a 0.019 $\mathrm{m}$ thick sheet of chemically resistant polyoxymethylene. Twenty $0.064 \mathrm{~m}$ diameter rings were cut into the disk to contain individual samples of oil. The samples were retained in polyvinylchloride cylindrical inserts $(0.060$ $\mathrm{m}$ i.d. and $0.042 \mathrm{~m}$ length) to allow for easy application and retrieval of oil during the studies. The polyoxymethylene disk is white in color and oil does not adhere to it. It does not absorb sunlight and thus its temperature does not increase noticeably relative to that of the water it floats in. The whole system was made buoyant by fixing a Styrofoam sheet (one inch thick) with a similar design to the bottom of the disk (the holes were aligned). The floating microcosm was placed into the circular flume tank under static (i.e. no flow) conditions.

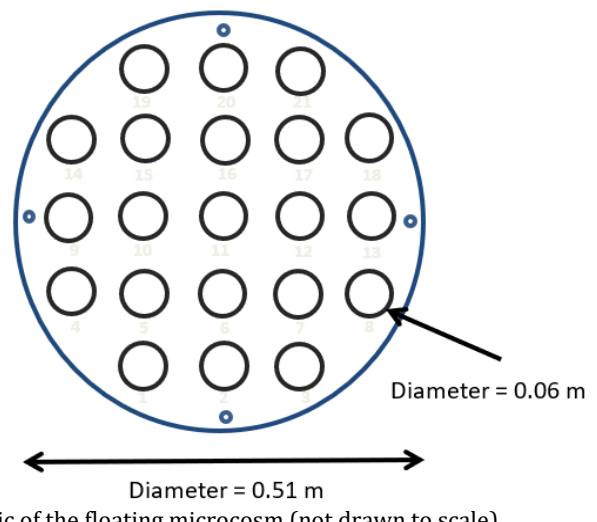

Fig. 2 Schematic of the floating microcosm (not drawn to scale)

\subsection{Environmental Conditions}

Only two seasons were considered for this study since the pumps in the system become inoperable under the freezing temperatures of Atlantic Canada during the winter and late fall. Environmental conditions (water and air temperatures, light energy, rainfall amounts and wind speeds) were recorded during the flume tank studies. The air temperature, rainfall amounts and wind speeds were recorded hourly by a Davis Vantage VUE weather station (model 6250; Scientific Sales Inc., NJ, USA) located near the tank. The salinity measurements were made using a hand held meter (YSI model \#30-1-FT; Yellow Springs, USA) at selected (refer to sample collection section below) points in time. Light intensity (wavelength range from 150 to $1200 \mathrm{~nm}$ ) and water temperature was measured using a in situ HOBO Pendant Data Logger made by ITM Instruments Inc. (Model UA002-08; Montreal, Canada). Light intensity and water temperature were measured 24 hours per day for the 192-hour study. Light intensity was greatest during sunlight (the main source of light) hours and least during cloud cover and night.

\subsection{Oil Application}

Approximately $12 \mathrm{~g}$ of oil was placed into each of the 20 numbered containment rings to achieve a $4 \mathrm{~mm}$ slick thickness, which would be later sampled at various points in time, for both spring (April-May) and summer (July-August) experiments carried out in 2017. Because oil slick thickness may have an effect on the rate of weathering of oil, slick thickness was controlled for comparative purposes. Also, uniform oil slicks in separate oil containment rings provided a convenient way to sample the oil at multiple points in time.

\subsection{Sample Collection}

Duplicate oil samples, from separate rings, were obtained at the following points in time: $0,3,8,24,48,72,96,120,144,168$, and 192 hours during oil weathering experiments. The duration was selected to be greater than the typical time of response after an oil spill, which ranges from 6 to 72 hours depending on the location and size of the spill [15]. The majority of the sample of oil was removed from the water surface using a spatula. The final sample mass was not measured, since it contained some water that would affect the total mass of oil recovered. 


\subsection{Analyses of Oil Samples and Data Analysis}

The viscosity and the density of each sample of unweathered and weathered oil were measured in triplicate using an Anton Paar SVM 3000 Viscometer following ASTM D7042 [16] and D5002 [17], respectively.

Multiple correlation analysis (Excel) was used to assess broad trends among the measured climatic parameters (air and water temperature, wind speed, and sunlight exposure) and the physical properties (density and viscosity) of oils weathered on water in spring and summer. Further to this, regression analysis (Excel, linear fit) was used to validate those trends that were identified through multiple correlation analysis and Analysis of Variance (ANOVA, Excel) was used to assess curve fit. ANOVA (repeated measures) was also applied to determine whether the season in which a spill occurred had an effect on the changes in the physical properties of the oils weathered at various points in time.

\subsection{Weathering Models}

King et al. [13] developed models for the density and viscosity of oil to capture the temporal evolution of oils during weathering. The underlying idea was to use modified Monod-type (or hyperbolic) models that allow for both the rapid initial changes and the slow long-term changes. The formulae are as follows:

$$
\begin{aligned}
& \rho=\rho_{0}+\left(\rho_{f}-\rho_{0}\right)\left(\frac{t}{T_{d}+t}\right)^{n_{d}} \\
& v=v_{0}+\left(v_{f}-v_{0}\right)\left(\frac{t}{T_{v}+t}\right)^{n_{v}}
\end{aligned}
$$

where $\rho$ and $v$ represents density and viscosity, respectively. The parameter " $t$ " represents time. The parameters " $T_{d}$ " and " $T_{v}$ " reflects the durations it takes to reach a steady state for the density $\left(T_{d}\right)$ or viscosity $\left(T_{v}\right)$. Thus, when $t=T_{\mathrm{d}}$, the density is half-way between the initial and final values. The power " $n$ " controls the rate at which the initial values ( $\rho_{0}$ or $\left.v_{0}\right)$ approach the final (or equilibrium) values ( $\rho_{\mathrm{f}}$ or $\nu_{\mathrm{f}}$ ); an " $n$ " value smaller than 1.0 represents a rapid initial increase in $\rho$ or $v$, whereas a value larger than 1.0 represents a rapid increase in $\rho$ or $v$ at latter times (similar to an exponential growth).

\section{Results and Discussion}

\subsection{Oil Products}

The physical properties of the selected oils are reported in Table 1 and more detailed information on the chemical composition is found in King et al. [18]. The blended bitumen products have similar densities and viscosities, since they are engineered to meet flow specifications required to transport oil by pipelines. Heavy crudes have an American Petroleum Institute (API) gravity value less than $22.3^{\circ}$ and medium crudes fall in the range of 22.3 to $31.1^{\circ}$ [19]. Based on the API gravity values (Table 1 ) the bitumen blends are classed as heavy oils. Heidrun is a conventional crude oil, and at $15{ }^{\circ} \mathrm{C}$ has a density similar to those of the diluted bitumen products, but its viscosity is approximately three times lower. With an API value of $23.3^{\circ}$, it just falls within the API gravity range of a medium crude oil.

Table 1 Physical properties (measured at $15^{\circ} \mathrm{C}$ ) of the oils used in the study

\begin{tabular}{llllll}
\hline Oil & Diluent & $\begin{array}{l}\text { Density } \\
\mathrm{g} / \mathrm{cm}^{3}\end{array}$ & $\begin{array}{l}\text { Viscosity } \\
\mathrm{cSt}\end{array}$ & $\mathrm{API}^{\circ}$ & Class* $^{*}$ \\
\hline AWB (dilbit) & $\begin{array}{l}\text { Condensate } \\
\text { WCS (dilsynbit) }\end{array}$ & 0.9208 & 244 & 22.4 & Heavy \\
& $\begin{array}{l}\text { Condensate/Synthetic } \\
\text { crude/light crude oil }\end{array}$ & 0.9214 & 211 & 21.9 & Heavy \\
Synbit & $\begin{array}{l}\text { Synthetic crude } \\
\text { Heidrun }\end{array}$ & 0.9304 & 205 & 20.4 & Heavy \\
none & 0.9132 & 68.9 & 23.3 & Medium \\
\hline
\end{tabular}

${ }^{*}$ Heavy crude has an $A P I<22.3^{\circ}$; medium crude has an API from 22.3 to $31.1^{\circ}$

(http://www.petroleum.co.uk/api)

\subsection{Seasonal Test Conditions}

Climatic parameters, including rainfall amounts, wind speed, air and water temperatures, and light intensity (solar radiation) were recorded during the experiments conducted in Atlantic Canada in 2017. The water temperature ranged from 1 to $7{ }^{\circ} \mathrm{C}$ in spring (April-May) and 13 to $19{ }^{\circ} \mathrm{C}$ in summer (July-August). Air temperature varied from 4 to $15^{\circ} \mathrm{C}$ and 14 to $27{ }^{\circ} \mathrm{C}$ for spring and summer experiments respectively. For both seasons during the experiments, the water salinity ranged from 28.7 to 31.0 partsper-thousand in the flume tank. Total rainfall amounts ranged from a few to 100 millimeters and didn't affect the salinity of the water in the flume tank during the experiments conducted in spring and summer. The wind speeds varied from 4 to $35 \mathrm{~km} / \mathrm{hr}$ in spring and 0 to $33 \mathrm{~km} / \mathrm{hr}$ in summer over the time-frame of the experiments. Light intensity varied for each oil https://doi.org/10.30799/jespr.176.19050305 weathering experiment, but the highest average values were 17000 lumens $/ \mathrm{m}^{2}$ in spring and 74,000 lumens $/ \mathrm{m}^{2}$ in summer.

\subsection{Difference in the Physical Properties of Weathered Oil}

The higher percentage (\%) difference in density (Eq. A1 (Appendix 1)) and viscosity (Eq. A2) occurred in the order of AWB (dilbit), WCS (dilsynbit), synbit, and Heidrun weathered on seawater in spring and summer (Tables A1 andA2 in the Appendix). This order was expected for the bitumen blends, since condensate diluents contain more lowmolecular weight volatiles (primarily aromatics and aliphatics in the range of $C_{5}$ to $C_{15}$ ) than does synthetic crude $[20,21]$. The conventional crude, Heidrun, showed the least percentage change in density and viscosity for both seasons (Table A1). Although Heidrun contains many of the same chemicals found in bitumen blends, it has a greater proportion of saturates $\left(\mathrm{C}_{10}\right.$ to $\mathrm{C}_{35}$ ) and alkylated polycyclic aromatic hydrocarbons (PAHs), which degrade more slowly over time [18]. In particular, alkylated PAHs have slower biodegradation rates than other hydrocarbons [22]. Also, the crude bitumen portion of the blended products contain more of the recalcitrant high-molecular weight resins and asphaltenes that would persist over the long-term (months to years) following its release in aquatic areas [18]

\subsection{Physical Properties of Oils Weathered on Sea Water}

Figs. 3 and 4 (semi-log) report the changes in densities and viscosities of the four oils weathered in spring and summer conditions. The figures' legends illustrate oil type and the average slick thickness of the oil, water temperature and wind speed. All density and viscosity measurements were conducted at $15{ }^{\circ} \mathrm{C}$ to allow direct comparison of the data for both seasons. Figs. 3 and 4; and Table 2 show that the final density and viscosity values were higher in the summer experiments compared to those in spring. For this study, the most significant changes in the physical properties were observed with AWB (dilbit) and the least with Heidrun crude oil for spring and summer data. AWB, WCS, and Synbit all had very similar densities and viscosities (engineered for flow specifications for transport by pipelines) prior to weathering, so the difference in the final physical property values of the diluted bitumen products is attributed to the rate of weathering of the diluent portion, which is different for each product tested.

None of the oil products had densities exceeding that of either fresh water $\left(1.0 \mathrm{~g} / \mathrm{cm}^{3}\right)$ or salt water $\left(1.03 \mathrm{~g} / \mathrm{cm}^{3}\right)$ over the two seasons (average water temperatures were $c a .6^{\circ} \mathrm{C}$ in spring and $c a .15{ }^{\circ} \mathrm{C}$ in summer). An earlier study by King et al [13] found that AWB's density more rapidly changed, when it was weathered at the same oil thickness on salt water with an average water temperature of $c a .22{ }^{\circ} \mathrm{C}$. This suggests that warmer water temperatures weaken the intermolecular forces of attraction among molecules in the oil and thus, increases the rate of evaporation of the condensate portion ( $\mathrm{ca} .30 \%$ ) of AWB weathered on water. Also, it is important note that under certain conditions, such as high temperature, high energy mixing and elevated suspended particles, the fate of oil can be affected by sedimentation $[3,6,7,23]$.

The viscosity data showed a trend similar to that observed for the density results, but followed an exponential increase over the same points in time. While water temperature contributed to increases in the viscosity (greater changes in summer than spring) as oil weathered, at higher temperatures (as noted from a previous study by King et al. [13]) the rate of diluent weathering increased significantly causing a much larger (an order of magnitude) increase in the viscosity of AWB.

\subsection{Model Results}

The previously developed models for density and viscosity, Eqs. 1 and 2 , respectively, were fitted to the physical properties data obtained from the weathering experiments. Parameter (' $T$ ' and ' $n$ ') values and the initial $\left(\rho_{0}, v_{0}\right)$ and final $\left(\rho_{\mathrm{f}}, \nu_{\mathrm{f}}\right)$ density and viscosity values respectively, for the models, are found in Table 1. The results reported in Figs. 3 and 4 show that the fits were generally good, with a clear absence of any systematic bias (undershooting or overshooting). The fit was also statistically significant as evidenced by the large coefficients of determination $\left(\mathrm{R}^{2}\right)$ that ranged from 0.83 to 0.99 (Table 2). The results show that the adopted models (Eqs. 1 and 2) were appropriate for capturing the different rates of changes in the densities and viscosities of oils after the initial release in spring and summer. In addition, the viscosity hyperbolic function was recently integrated with a new chemical dispersion model to estimate dispersant effectiveness to treat spills on water at various points in time after the initial release [24]. The final values of density and viscosity of oil weathered in summer were relatively much higher than those in spring, and thus the larger ' $T$ ' value in summer reflects a more strongly weathered oil. The ' $T$ ' value was smaller for the density than for the viscosity, suggesting that the density rapidly changed initially while the viscosity continued to change (namely increase) at an exponential rate with time. 
The ' $n$ ' value was generally less than 1.0 for density and greater than 1.0 for viscosity for the oil sands products. The latter is consistent with exponential models for viscosity increases due to weathering [3].

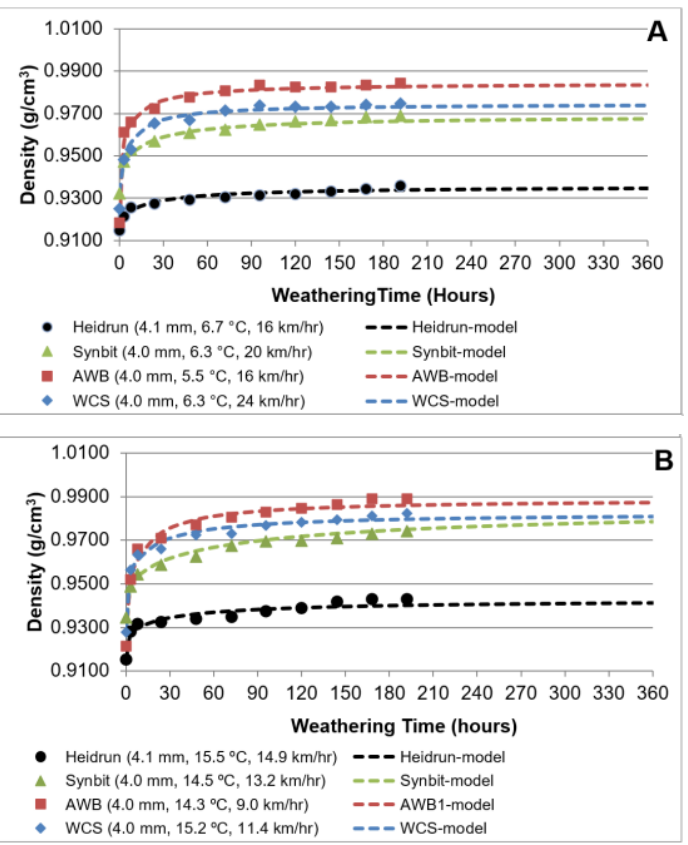

Fig. 3 Densities of oils as a function of time of weathering: A) spring-time conditions and B) summer-time conditions. The figures' legends illustrate oil type and the average slick thickness of the oil, water temperature and wind speed. Raw data reported in Appendix Table A1.

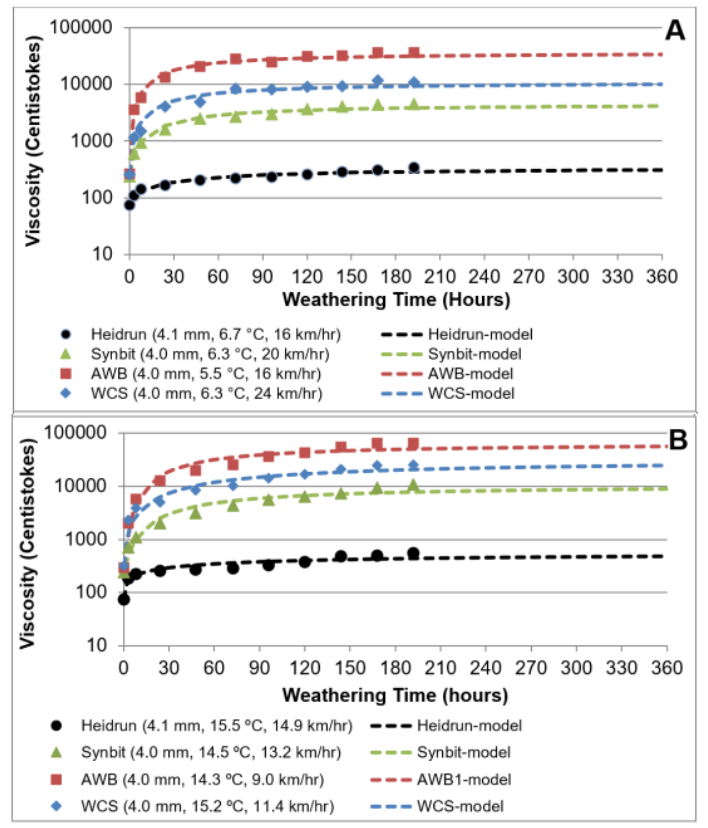

Fig. 4 Viscosities of oils as a function of time of weathering: A) spring-time conditions and B) summer-time conditions. The figures' legends illustrate oil type and the average slick thickness of the oil, water temperature and wind speed. Raw data reported in Appendix Table A2.

Table 2 Parameter values (' $T$ ' and ' $n$ ') of the density and viscosity models, Eqs. 1 and 2 , fitted to the empirical data for the weathering of different oils. $\mathrm{R}^{2}$-coefficient of determination and $\rho_{0}, \rho_{\mathrm{f}}, v_{\mathrm{o}}$ and $v$ represent the initial and final density and viscosity values, respectively.

\begin{tabular}{|c|c|c|c|c|}
\hline $\begin{array}{l}\text { Oil } \\
\text { (thickness, temperature, wind speed)* }\end{array}$ & Initial; Final Values & $\begin{array}{l}T \\
(\mathrm{hr})\end{array}$ & $n$ & $\mathrm{R}^{2}$ \\
\hline Density (raw data in Table A1) & $\mathrm{g} / \mathrm{cm}^{3}$ & & & \\
\hline AWB $\left(4.0 \mathrm{~mm}, 5.5^{\circ} \mathrm{C}, 16.4 \mathrm{~km} / \mathrm{hr}\right)$ Spring & $\rho_{0=0.9181 ;} \rho_{f=0.9843}$ & 16 & 0.33 & 0.99 \\
\hline $\begin{array}{l}\text { AWB }\left(4.1 \mathrm{~mm}, 14.3{ }^{\circ} \mathrm{C}, 9.0 \mathrm{~km} / \mathrm{hr}\right) \\
\text { Summer }\end{array}$ & $\rho_{0=0.9214 ;} \rho_{f=0.9888}$ & 21 & 0.42 & 0.98 \\
\hline WCS $\left(4.1 \mathrm{~mm}, 6.3^{\circ} \mathrm{C}, 24.7 \mathrm{~km} / \mathrm{hr}\right)$ Spring & $\rho_{0=0.9252} ; \rho_{f=0.9745}$ & 11 & 0.55 & 0.96 \\
\hline $\begin{array}{l}\text { WCS }\left(4.0 \mathrm{~mm}, 15.2^{\circ} \mathrm{C}, 11.8 \mathrm{~km} / \mathrm{hr}\right) \\
\text { Summer }\end{array}$ & $\rho_{0=0.9277 ;} \rho_{f=0.9839}$ & 41 & 0.28 & 0.98 \\
\hline
\end{tabular}

\begin{tabular}{|c|c|c|c|c|}
\hline $\begin{array}{l}\text { Synbit }\left(4.0 \mathrm{~mm}, 6.3^{\circ} \mathrm{C}, 20.5 \mathrm{~km} / \mathrm{hr}\right) \\
\text { Spring }\end{array}$ & $\rho_{0=0.9324 ;} \rho_{f=0.9688}$ & 40 & 0.38 & 0.98 \\
\hline $\begin{array}{l}\text { Synbit }\left(4.0 \mathrm{~mm}, 14.5^{\circ} \mathrm{C}, 13.2 \mathrm{~km} / \mathrm{hr}\right) \\
\text { Summer }\end{array}$ & $\rho_{0=0.9386 ;} \rho_{f=0.9853}$ & 220 & 0.29 & 0.96 \\
\hline $\begin{array}{l}\text { Heidrun }\left(4.2 \mathrm{~mm}, 6.7^{\circ} \mathrm{C}, 13.6 \mathrm{~km} / \mathrm{hr}\right) \\
\text { Spring }\end{array}$ & $\rho_{0=0.9212 ;} \rho_{f=0.9356}$ & 48 & 0.41 & 0.97 \\
\hline $\begin{array}{l}\text { Heidrun }\left(4.1 \mathrm{~mm}, 15.5^{\circ} \mathrm{C}, 14.9 \mathrm{~km} / \mathrm{hr}\right) \\
\text { Summer }\end{array}$ & $\rho_{0=0.9151 ;} \rho_{f=0.9429}$ & 95 & 0.25 & 0.94 \\
\hline Viscosity (raw data in Table A2) & Centistokes & & & \\
\hline AWB $\left(4.0 \mathrm{~mm}, 5.5^{\circ} \mathrm{C}, 16.4 \mathrm{~km} / \mathrm{hr}\right)$ Spring & $\begin{array}{c}v_{0}=265 \\
v_{f}=36646\end{array}$ & 28 & 1.1 & 0.95 \\
\hline $\begin{array}{l}\text { AWB }\left(4.1 \mathrm{~mm}, 14.3^{\circ} \mathrm{C}, 9.0 \mathrm{~km} / \mathrm{hr}\right) \\
\text { Summer }\end{array}$ & $\begin{array}{l}v_{0}=299 \\
v_{f}=69309\end{array}$ & 29 & 1.8 & 0.86 \\
\hline WCS $\left(4.1 \mathrm{~mm}, 6.3^{\circ} \mathrm{C}, 24.7 \mathrm{~km} / \mathrm{hr}\right)$ Spring & $\begin{array}{c}v_{0}=260 \\
v_{f}=11053\end{array}$ & 34 & 1.1 & 0.92 \\
\hline $\begin{array}{l}\text { WCS }\left(4.0 \mathrm{~mm}, 15.2^{\circ} \mathrm{C}, 11.8 \mathrm{~km} / \mathrm{hr}\right) \\
\text { Summer }\end{array}$ & $\begin{array}{l}v_{0}=308 \\
v_{f}=25073\end{array}$ & 110 & 0.97 & 0.90 \\
\hline $\begin{array}{l}\text { Synbit }\left(4.0 \mathrm{~mm}, 6.3^{\circ} \mathrm{C}, 20.5 \mathrm{~km} / \mathrm{hr}\right) \\
\text { Spring }\end{array}$ & $\begin{array}{l}v_{0}=240 \\
v_{f}=4580\end{array}$ & 40 & 0.98 & 0.93 \\
\hline $\begin{array}{l}\text { Synbit }\left(4.0 \mathrm{~mm}, 14.5^{\circ} \mathrm{C}, 13.2 \mathrm{~km} / \mathrm{hr}\right) \\
\text { Summer }\end{array}$ & $\begin{array}{l}v_{0}=242 \\
v_{f}=10924\end{array}$ & 52 & 1.3 & 0.87 \\
\hline $\begin{array}{l}\text { Heidrun }\left(4.2 \mathrm{~mm}, 6.7^{\circ} \mathrm{C}, 13.6 \mathrm{~km} / \mathrm{hr}\right) \\
\text { Spring }\end{array}$ & $\begin{array}{l}v_{0}=75 \\
v_{f}=345\end{array}$ & 80 & 0.64 & 0.93 \\
\hline $\begin{array}{l}\text { Heidrun }\left(4.1 \mathrm{~mm}, 15.5^{\circ} \mathrm{C}, 14.9 \mathrm{~km} / \mathrm{hr}\right) \\
\text { Summer }\end{array}$ & $\begin{array}{l}v_{0}=75 \\
v_{f}=695\end{array}$ & 250 & 0.36 & 0.83 \\
\hline
\end{tabular}

\subsection{Multiple Correlation Analysis}

In order to identify whether there were broad trends with the measured climatic parameters (rainfall, light intensity [solar radiation], wind speed, and air and water temperatures) and changes in the physical properties (density and viscosity) of the oils weathered on water, multiple correlation analysis was conducted on the data set (Tables A3-A6). Rainfall amounts were sporadic and zero values were recorded for most of the points in time during the experiments, so it was not assessed due to limited data. Also, salinity recordings were constant and not expected to affect the changes in physical properties of oil weathered on sea water [25]; however, the presence of electrolytes (potassium, sodium and chloride) could affect the dissolution of the water-soluble chemicals from oil to water [26]. The average values for the climatic parameters (air and water temperature, light intensity [solar radiation], wind speeds) and physical properties measurements at the corresponding points in time were used in the evaluation. The trends identified through correlation analysis were validated using regression analysis. The linear trends with the physical properties (density and viscosity) of different oils and the climatic parameters (light intensity [solar radiation], water and air temperatures and wind speed) that influence the rates of weathering of the oils are shown in Fig. 5 and 6. The results of the regression analysis $\left(\mathrm{R}^{2}\right.$ ranging from 0.6 to 0.8$)$ and Analysis of Variance to assess significant $(p<0.05)$ curve fit are reported in Tables A7 (density) and A8 (viscosity) of the Appendix.

A previous report suggested that temperature and time were greater parameters in the weathering (mostly evaporation) of oil than surface wind speed or oil slick thickness for a wide range of crude oils [27]. In contrast, Gros et al. [28] determined that wind speed strongly affected the weathering (evaporation) of oil very early in an experimental spill of a Norwegian crude in the North Sea. Since the oil sands products have different proportions of saturates, aromatics, resins and asphaltenes (affected by the type of diluent used) they were separately assessed as follows.

For weathering of AWB on water in spring-time conditions, water temperature and solar radiation had an effect on the changes in the density and viscosity of the oil over the 192-hour study (Figs. 5A and 6A; Tables A7 and A8). As temperature increases (through water and heat from solar radiation) the intermolecular forces of attraction in the oil become weaker, increasing the rate of evaporation. However, the rates of changes in the physical properties of AWB was limited by decreasing water temperature and solar radiation exposure over the length of the experiment. AWB's density increased with exposure to wind and solar radiation during the experiment conducted in summer (Fig. 5 and Table A7). The wind speed decreased over the length of the experiment, which limited the rate of evaporation of volatile chemicals from AWB. The relationship between light intensity (solar radiation) and the rate of 
change in the density of AWB may be the result of evaporation, since solar radiation would heat the oil at the surface as it weathered on water. In addition, there may have been some photo-chemical weathering of AWB, but it may have been affected by a reduction in light intensity (solar radiation) over the length of the study. Photo-chemical weathering generally contributes to changes in the density of an oil as its chemical composition changes. For example, in lab experiments, the photochemical oxidation of oil on water under direct ultraviolet irradiation showed oxidation of $5 \%$ branched alkanes, $9 \%$ of n-alkanes and 37\% aromatics to water soluble forms leaving high molecular weight resins and asphaltenes behind $[4,29,30]$. These oxygenated chemicals are expected to persist in the environment and can be carried by water flow [31]. The changes in the viscosity of AWB weathered in summer were due mostly to air temperature, since wind speed decreased over the length of the experiment (Fig. 6B and Table A8). The warmer air temperature in summer caused evaporation of volatile chemicals $\left(<\mathrm{C}_{10}\right)$, resulting in thicker more viscous oil slicks. A recent lab study [10] reported that both evaporation and photo-chemical oxidation result in increases in the density and viscosity of oil, but the increases were predominately higher for oil exposed to solar radiation. However, AWB contains condensate as the diluent, a liquid product of natural gas extraction. Condensate's chemical composition is primarily composed of low molecular weight aromatics and aliphatic in the range of $\mathrm{C}_{5}$ to $\mathrm{C}_{15}$, which are susceptible to evaporation [20]. However, the crude bitumen portion, of AWB, contains aromatics and their alkylated homologues [18] that are susceptible to photo-chemical weathering.

Water temperature, increasing over the length of the experiment, was strongly correlated to the changes in the density of WCS weathered in spring conditions (Fig. 5A and Table A7). Air temperature had an effect on the viscosity of oil in spring, but was limited as temperature decreased over the length of the experiment. Also, the changes in both the density and viscosity of the oil was linked to light intensity (decreasing over the length of the experiment) where it most likely heated the oil at the surface of the water in spring. This suggests that evaporation influenced the weathering of the oil in spring. Air temperature, decreasing during the experiment, affected changes in the density of WCS weathered in summer. Light intensity (solar radiation) and water temperature affected the changes in the viscosity (Fig. 6 and Table A8) of WCS in summer. This suggests that evaporation and photo-chemical weathering of the oil contributed to the rates of changes in the viscosity of the oil, but photochemical weathering was limited by a reduction in solar radiation and evaporation was encouraged, through increasing water temperature, over the length of the study. Similar to AWB, WCS contains condensate (but in a reduced amount) as diluent, which is more susceptible to evaporative weathering than the crude bitumen portion of the product. WCS also contains synthetic crude, as a portion of the diluent, which is less susceptible to evaporative weathering.

The level and duration of solar radiation and wind speed affected the density and viscosity of Synbit weathered on water in spring (Figs. 5 and 6; Tables A7 and A8). Wind speed increased and light intensity (solar radiation) decreased over the length of the spring study. This suggests that evaporation was more active than photo-chemical weathering of synbit in spring. For the summer results, light intensity, the only parameter affecting changes in the physical properties, increased over time suggesting that photo-chemical weathering or evaporation of synbit as it heated at the water surface. Synbit's composition contains a greater portion of saturates in the range of $\mathrm{C}_{17}$ to $\mathrm{C}_{35}$ and alkylated polycyclic aromatics [32] that are less susceptible to evaporative weathering than condensate. A recent study reported a reduction of saturates and aromatics through the photo-chemical weathering of diluted bitumen spilled on temperate salt water [33], which substantiates our results that solar radiation may play a major role in the weathering of Synbit in summer. Therefore, we considered that although some evaporation occurred to remove volatile chemicals $\left(<\mathrm{C}_{10}\right)$, photo-chemical oxidation would play a major role in the weathering of the non-volatile $\left(>C_{10}\right)$ portion of Synbit.

Light intensity (solar radiation) was the only climatic parameter associated with the changes in the density and viscosity of Heidrun weathered on water over the two seasons (Figs. 5A and 6A; Tables A7 and A8). The level of exposure and duration of solar radiation was greater in summer than spring.

This suggests that photo-chemical oxidation was a major contributor to the weathering of the conventional crude, Heidrun. Heidrun's chemical composition contains a higher percentage of aromatics [18] that are more susceptible to photo-chemical weathering. However, its influence on the changes in the physical properties of Heidrun was limited, since solar radiation decreased over the length of the experiments conducted in both seasons. The results for Heidrun are substantiated by the work of others, where photo-chemical weathering had a major influence on the rates of https://doi.org/10.30799/jespr.176.19050305 changes in the physical properties of a conventional crude oil spilled in water [10].

Microbes that consume saturates and aromatics present in oil have been reported to response to AWB spilled in the sea water collected from the Bedford Basin [34]. However, since no nutrients were added to the sea water for our weathering studies, low rates of biodegradation of the tested oil products were expected based on the results of previous studies $[34,35]$. Of the climatic parameters assessed it has been reported that temperature affects the rates of biodegradation of oils [36-38]. A recent study suggests that the biodegradation of AWB is limited in cold water ( $\mathrm{ca}$. $6{ }^{\circ} \mathrm{C}$ ) from the Bedford Basin [25], the water source for this study. It has been reported that sunlight can stimulate oil-degrading bacteria [39]. This suggests that biodegradation may have played some role in the changes in the physical properties of the oils weathered over the two seasons. It is important to note that the diluent portion of the diluted bitumens are readily susceptible to microbial degradation more so than the large fraction of resins ( 50 to $70 \%$ ) and asphaltenes within the bitumen fraction [18] that are likely to be highly recalcitrant to biological processes. Also, there can be different rates of biodegradation for the oils, depending on their chemical composition (\% saturates and aromatics) [38].

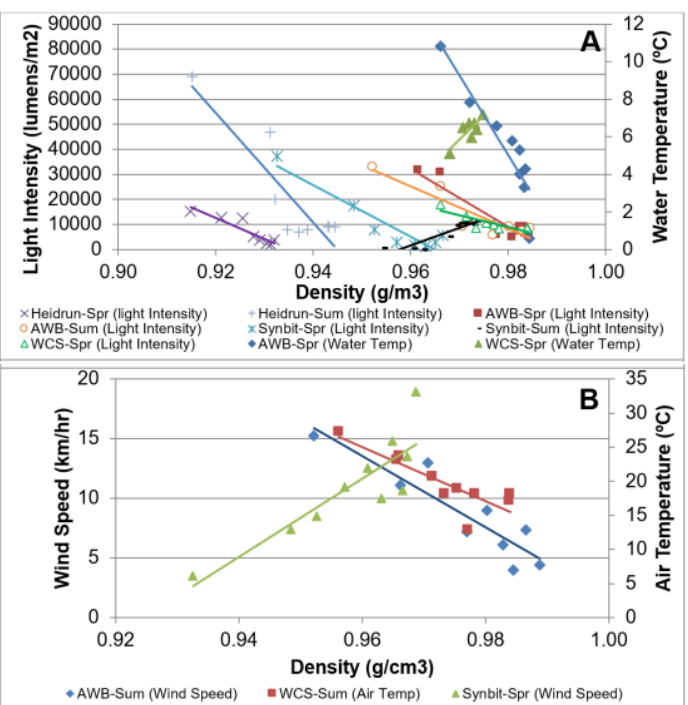

Fig. 5 Densities of oils as a function of climatic parameters: (A) light intensity (solar radiation) and water temperature and B) wind speed and air temperature. All graphical data represent the average values at the selected points in time in section 2.6. Slopes and $\mathrm{R}^{2}$ values for linear regression are found in Table A7.

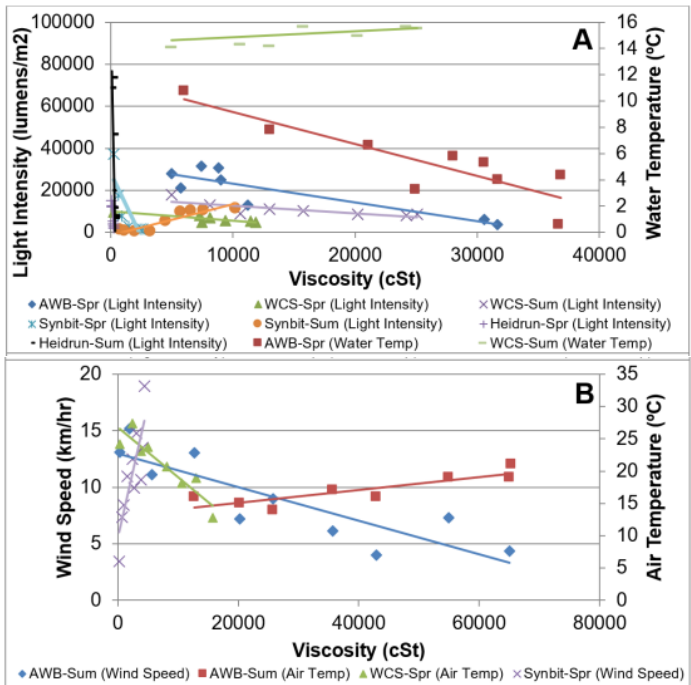

Fig. 6 Viscosities of oils as a function of climatic parameters: (A) light Intensity (solar radiation) and water temperature and $B$ ) wind speed and air temperature. All graphical data represent the average values at the selected points in time in section 2.6. Slopes and $\mathrm{R}^{2}$ values for linear regression are found in Table A8.

\subsection{Analysis of Variance (Repeated Measures)}

Analysis of Variance (ANOVA repeated measures, Excel) was used to investigate the changes in the physical properties of the oils as they weathered over time for the two seasons. Each of the oils was assessed separately for density and viscosity. Season had a significant $(p<0.01)$ 
effect on the changes in the densities and viscosities of the oils weathered on water (Table 3 ).

Table 3 ANOVA (repeated measures; Excel) comparing the effects of season on the changes in densities and viscosities of oils weathered on sea water

\begin{tabular}{lllll}
\hline Oil Type & ${ }^{\wedge}$ Source of Variation & ${ }^{*} n$ & ${ }^{* *} R M S E$ & ${ }^{\wedge} p$-value \\
\hline Density & Between Spr and Sum & 10 & 0.005 & 0.009 \\
AWB & Between Spr and Sum & 10 & 0.01 & 0.008 \\
WCS & Between Spr and Sum & 10 & 0.005 & 0.008 \\
Synbit & Between Spr and Sum & 10 & 0.01 & 0.001 \\
Heidrun & & & \\
Viscosity & & & 35000 & 0.009 \\
AWB & Between Spr and Sum & 10 & 16000 & 0.003 \\
WCS & Between Spr and Sum & 10 & 6500 & 0.005 \\
Synbit & Between Spr and Sum & 10 & 260 & 0.004 \\
Heidrun & Between Spr and Sum & 10 & &
\end{tabular}

${ }^{\wedge}$ Season is the source of the variation or independent variable, which is represented by the difference in the climatic parameters. The dependent variables are density and viscosity, since they are increasing at different rates as a result of the changes in season. ${ }^{*} n=n 1+n 2:$ Therefore ' $n$ ' is the number of mean physical property values (density and viscosity) in spring (n1) added to the number of mean physical property values (density and viscosity) in summer (n2) over the same time points. ${ }^{* *}$ RMSE-Root Mean Square Error, ${ }^{\wedge}{ }^{\wedge} p$-value significant at $<0.01$.

The results, for ANOVA, showed greater rates of changes in the physical properties of the oils weathered in summer than spring for the points in time ranging 96 to 192 hours. Assessment of changes in the physical properties of oils weathered up to 96 hours showed season had no significant difference, so it was not reported. Figs. 3 and 4 demonstrate that there were more rapid rates of changes in the physical properties of the oils weathered up to 96 hours over both seasons. The rapid rates of changes in the physical properties of the oils most likely suggest evaporation of the volatile chemicals $\left(<\mathrm{C}_{10}\right)$. The significant rates of changes in the physical properties (in the later stages 96 to 192 hours) of oil suggest photo-chemical weathering and/or biodegradation of the nonvolatile chemicals $\left(>\mathrm{C}_{10}\right)$ was greater in summer than spring. However, within a similar time-scale of previous experiments conducted in the Bedford Basin, evidence of diluted bitumen biodegradation was limited.

\section{Conclusion}

The densities of all three diluted bitumen products weathered on water during spring and summer were less than the density of salt water $(1.03$ $\mathrm{g} / \mathrm{cm}^{3}$ ). This suggests that after 192 hours of weathering, under similar conditions, the products would remain floating on sea water. The experiments might underestimate the extent of oil weathering in open water where the oil can become thinner and dispersed by waves.

The results show that the previously developed hyperbolic models were appropriate for capturing the changes in the densities and viscosities of oils after a spill in spring and summer. In addition, ANOVA showed that season (later stages 96 to 192 hours) had a significant ( $p<0.01$ ) effect on the rates of changes in the densities and viscosities of all the tested oils weathered on water. The different rates of changes in the physical properties of nonconventional oils suggest that the diluent used in each specific product formulation, greatly affects the rate of weathering of the original product spilled in aquatic areas. In terms of physical oil spill recovery, as the diluent in Synbit is less susceptible to natural attenuation, it would provide an extended amount of time available for clean-up operations at sea under similar conditions in comparison to other product formulations.

Multiple correlations analysis coupled with regression analysis revealed that significant $(p<0.05)$ trends exist with the seasonal climatic parameters and the changes in the densities and viscosities of the oils weathered on water. Temperature, wind speed, and the duration and intensity of solar radiation were all contributing parameters in the weathering of the diluted bitumen products, depending on oil type or, in this case, the diluent blended with crude bitumen. Solar radiation was the only measured climatic parameter significantly affecting the weathering of the conventional crude oil, Heidrun. The production of oxidized chemicals from the photo-chemical weathering of oil could provide implications for oil spill response planning if natural dilution and mixing, of water-soluble oxygenated hydrocarbons, are minimal in the affected area. The information provided on the influence of climatic conditions on changes in the density and viscosity of spilled petroleum hydrocarbons may be used to select the optimal oil spill response options (e.g. natural attenuation vs mechanical recovery) in the event of a spill. Furthermore, in light of global climate change, there is a need to improve our understanding of climatic parameters and their influence on the physical properties of residual oil after a spill to develop future preparedness and response plans.

https://doi.org/10.30799/jespr.176.19050305

\section{Acknowledgement}

The authors would like to acknowledge the assistance of Claire McIntyre and Graeme Soper for the physical properties' measurement of the oil samples.

\section{References}

[1] National Resources Canada (NRCan), Crude oil and energy facts https://www.nrcan.gc.ca/energy/facts/crude-oil/20064 (Accessed on 01.08.2019).

[2] National Energy Board, Crude oil and petroleum products, https://www.nebone.gc.ca/nrg/sttstc/crdlndptrlmprdct/index-eng.html (Accessed on: 01.08.2019)

[3] K. Lee, M. Boufadel, B. Chen, F. Foght, P. Hodson, et al., Expert panel report on the behaviour and environmental impacts of crude oil released into aqueous environments, Royal Society of Canada, ON, Canada, 2015.

[4] National Academies of Sciences (NAS), Spills of diluted bitumen from pipelines: a comparative study of environmental fate, effects, and response, National Academy Press, Washington, USA, 2016.

[5] M. Boufadel, X. Geng, J. Short, Bioremediation of the Exxon Valdez oil spill in Prince William Sound beaches, Mar. Pollut. Bull. 113 (2016) 156-154.

[6] L. Zhao, M. Boufadel, X. Geng, K. Lee, T. King, et al., A-Drop: A predictive mode for the formation of oil particle aggregates (OPAs), Mar. Pollut. Bull. 106 (2016) 245-259.

[7] L. Zhao, M. Boufadel, J. Katz, G. Haspel, K. Lee, et al., A new mechanism of sediment attachment to oil in turbulent flows, Environ. Sci. Technol. 51 (2017) 11020-11029.

[8] S. Ross, I. Buist, Preliminary lab study to determine the effects of emulsification on oil spill evaporation, Proceeding of the eighteen Arctic and Marine Oil Spill Program (AMOP), Technical Seminar, Environment and Climate Change, Canada, 1995, pp.91-110.

[9] M. Fingas, Evaporation of oil spills: development and implementation of new prediction methodology, Proceeding of the International Oil Spill Conference, Allen Press Inc., United States of America, 1999, pp.281-287.

[10] C. Ward, C. Armstrong, R. Conmy, D. French-McCay, C. Reddy, Photochemica oxidation of oil reduced the effectiveness of aerial dispersants applied in response to the deepwater horizon spill, Env. Sci. Technol. Let. 5 (2018) 226231.

[11] C. Aeppli, R. Swarthout, G. O'Neil, S. Katz, D. Nabi, et al., How persistent and bioavailable are oxygenated Deepwater Horizon oil transportation products? Env. Sci. Technol. 52 (2018) 7250-7258.

[12] R. Prince, Oil spill dispersants: boon or bane?, Env. Sci. Technol. 49 (2015) 6376-6384.

[13] T. King, B. Robinson, F. Cui, M. Boufadel, K. Lee, J. Clyburne, An oil spill decision matrix in response to surface spills of various bitumen blends, Env. Sci.: Proc Imp. 19 (2017) 929-939.

[14] Canadian Association of Petroleum Producers (CAPP), Crude oil forecasts, markets and transportation, https://context.capp.ca/articles/2017/feature_crudeoilforecast_2017 (Accessed on: 01.08.2019).

[15] Transport Canada, Response organizations standards, https://www.tc.gc.ca/media/documents/marinesafety/tp12401e.pdf (Accessed on: 01.08.2019)

[16] ASTM D7042, Standard test method for dynamic viscosity and density of liquids by Stabinger Viscometer (and the Calculation of Kinematic Viscosity), ASTM International, PA, USA, 2014.

[17] ASTM D 5002, Standard test method for density and relative density of crude oils by digital density analyzer, ASTM International, PA, USA, 2010.

[18] T. King, J. Mason, P. Thamer, G. Wohlgeschaffen, K. Lee, J. Clyburne, Composition of bitumen blends relevant to ecological impacts and spill response, Proceedings of the $40^{\text {th }}$ AMOP Technical Seminar, Environment and Climate Change, Canada, 2017, pp.463-475.

[19] Petroleum.co.uk, API gravity, 2015, http://www.petroleum.co.uk/ap (Accessed on: 01.08.2019).

[20] Government of Canada, Order Adding Toxic Substances to Schedule 1 to the Canadian Environmental Protection Act, 1999, amendment 139, http://www.gazette.gc.ca/rp-pr/p2/2018/2018-02-21/html/sor-dors20eng.html (Accessed on: 01.08.2019).

[21] M. Fingas, Review of the properties and behaviours of diluted bitumen. Proceeding of the 39th Arctic and Marine Oil Spill Program Technical Seminar, Environment and Climate Change, Canada, 2015, pp.470-494.

[22] A. Oberoi, L. Philip, Variation in toxicity during the biodegradation of various heterocyclic and homocyclic aromatic hydrocarbons in single and multisubstrate system, Ecotoxico. Env. Safe. 135 (2016) 337-346.

[23] National Research Council, Spills of nonfloating oils: risk and response, National Academy Press, Washington, USA, 1999.

[24] T. King, B. Robinson, S. Ryan, K. Lee, M. Boufadel, J. Clyburne, Estimating the usefulness of chemical dispersant to treat surface spills of oil sands products, J. of Mar. Sci. Eng. 6 (2018) 128:1-16.

[25] T. King, B. Robinson, P. Toole, J. Clyburne, Access Western Blend (dilbit) weathered on cold fresh and marine salt waters, Proceeding of the FortySecond Arctic and Marine Technical Seminar, Institute, Country, 2019, pp.847858.

[26] W. Xie, W. Shiu, D. Mackay, A Review of the effects of salts on the solubility of organic compounds in seawater, Marine Environ. Res. 44(4) (1997) 429-444.

[27] M. Fingas, Modeling evaporation using models that are not boundary-layer regulated, J. Hazard. Mater. 107 (2004) 27-36. 
[28] J. Gros, D. Nabi, B. Würz, L. Wick, C. Brussaard, et al., First day of an oil spill on the open sea: early mass transfers of hydrocarbons to air and water, Env. Sci. Technol. 48 (2014) 9400-9411.

[29] R. Prince, R. Garrett, R. Bare, M. Grossman, T. Townsend, et al., The roles of photooxidation and biodegradation in long-term weathering of crude and heavy fuel oils, Spill Sci. Technol. Bull. 8 (2003) 145-156.

[30] C. Aeppli, C. Carmichael, R. Nelson, K. Lemkau, W. Graham, et al., Oil weathering after the Deepwater Horizon disaster led to the formation of oxygenated residues, Env. Sci. Technol. 46 (2012) 8799-8807.

[31] F. Chapelle, Ground-water microbiology and geochemistry, Second Ed., John Wiley \& Sons, New Jersey, USA, 2001.

[32] C. Yang, Z. Wang, Z Yang, B. Hollebone, C. Brown, et al., Chemical fingerprints of Alberta oil sands and related petroleum products, Environ. Forensics 12 (2011) 173-188.

[33] Z. Yang, G. Zhang, B. Hollebone, C. Brown, C. Yang, et al., Fate of oxygenated intermediates in solar irradiated diluted bitumen mixed with saltwater, Env. Poll. 231 (2017) 622-634.

[34] A. Ortmann, S. Cobanli, G. Wohlgeschaffen, P. Thamer, C. McIntyre, et al., Inorganic nutrients have a significant, but minimal, impact on coastal microbial community's response to fresh diluted bitumen, Mar. Pollut. Bull. 139 (2019) 381-389.

[35] T. King, B. Robinson, M. Boufadel, K. Lee, Flume tank studies to elucidate the fate and behaviour of diluted bitumen spilled at sea, Mar. Pollut. Bull. 83 (2014) 32-37.

[36] J. Tremblay, E. Yergeau, N. Fortin, S. Cobanli, M. Elias, et al., Chemical dispersants enhance the activity of oil- and gas condensate-degrading marine bacteria, Int. Soc. Microbial Ecol. 11 (2017) 2793-2808.

[37] L. Schreiber, N. Fortin, J. Tremblay, J. Wasserscheid, M. Elias, et al., Potential for microbially mediated natural attenuation of diluted bitumen on the coast of British Columbia (Canada), Appl. Environ. Microbiol. 85(10) (2019) 1-19.

[38] R. Deshpande, D. Sundaravadivelu, P. Campo, J. SantoDomingo, R. Conmy, Comparative study on rate of biodegradation of diluted bitumen and conventional oil in fresh water, Proceeding of the International Oil Spill Conference, Allen Press Inc., United States of America, 2017, pp.2256-2267.

[39] H. Bacosa, Z. Liu, D. Erdner, Natural sunlight shapes crude oil-degrading bacterial communities in Northern Gulf of Mexico surface waters, Front. Microbiol. 6 (2015) 1325:1-14.

\section{Appendix}

The raw data for the density and viscosity measurements are found in Tables A1 to A2.

$\%$ Difference $=\frac{\left(\rho_{f}-\rho_{i}\right)}{\frac{\left(\rho_{f}-\rho_{i}\right)}{2}}$

where $\rho_{f}$ and $\rho_{i}$ are the final and initial density values respectively.

Table A1 Average (average \pm standard deviation): 6 values; 3 measurements for duplicate experiments) density data for all oils weathered on seawater in spring and summer conditions. Density values were measured at $15{ }^{\circ} \mathrm{C}$.

\begin{tabular}{|c|c|c|c|c|}
\hline Sampling Time (Hours) & $\mathrm{AWB}\left(\mathrm{g} / \mathrm{cm}^{3}\right)$ & $\mathrm{WCS}\left(\mathrm{g} / \mathrm{cm}^{3}\right)$ & Synbit $\left(\mathrm{g} / \mathrm{cm}^{3}\right)$ & Heidrun $\left(\mathrm{g} / \mathrm{cm}^{3}\right)$ \\
\hline \multicolumn{5}{|c|}{ Weathering Study (Spring) } \\
\hline 0 & $0.9181 \pm 0.0003$ & $0.9252 \pm 0.0001$ & $0.9326 \pm 0.0003$ & $0.9149 \pm 0.0002$ \\
\hline 3 & $0.9596 \pm 0.0017$ & $0.9491 \pm 0.0013$ & $0.9484 \pm 0.0016$ & $0.9212 \pm 0.0023$ \\
\hline 8 & $0.9684 \pm 0.0400$ & $0.9538 \pm 0.0038$ & $0.9526 \pm 0.0001$ & $0.9255 \pm 0.0005$ \\
\hline 24 & $0.9719 \pm 0.0001$ & $0.9652 \pm 0.0002$ & $0.9572 \pm 0.0017$ & $0.9277 \pm 0.0005$ \\
\hline 48 & $0.9781 \pm 0.0017$ & $0.9680 \pm 0.0002$ & $0.9609 \pm 0.0005$ & $0.9291 \pm 0.0064$ \\
\hline 72 & $0.9807 \pm 0.0004$ & $0.9708 \pm 0.0012$ & $0.9631 \pm 0.0012$ & $0.9305 \pm 0.0003$ \\
\hline 96 & $0.9816 \pm 0.0022$ & $0.9724 \pm 0.0019$ & $0.9650 \pm 0.0002$ & $0.9313 \pm 0.0002$ \\
\hline 120 & $0.9816 \pm 0.0014$ & $0.9719 \pm 0.0001$ & $0.9666 \pm 0.0003$ & $0.9320 \pm 0.0005$ \\
\hline 144 & $0.9820 \pm 0.0006$ & $0.9731 \pm 0.0003$ & $0.9673 \pm 0.0004$ & $0.9332 \pm 0.0002$ \\
\hline 168 & $0.9830 \pm 0.0006$ & $0.9735 \pm 0.0028$ & $0.9687 \pm 0.0001$ & $0.9341 \pm 0.0005$ \\
\hline 192 & $0.9834 \pm 0.0003$ & $0.9748 \pm 0.0010$ & $0.9692 \pm 0.0004$ & $0.9356 \pm 0.0024$ \\
\hline$\%$ Difference & 6.9 & 5.2 & 3.8 & 2.2 \\
\hline \multicolumn{5}{|c|}{ Weathering Study (Summer) } \\
\hline 0 & $0.9210 \pm 0.0011$ & $0.9274 \pm 0.0010$ & $0.9373 \pm 0.0004$ & $0.9151 \pm 0.0002$ \\
\hline 3 & $0.9512 \pm 0.0027$ & $0.9562 \pm 0.0013$ & $0.9499 \pm 0.0002$ & $0.9280 \pm 0.0002$ \\
\hline 8 & $0.9652 \pm 0.0012$ & $0.9657 \pm 0.0020$ & $0.9543 \pm 0.0002$ & $0.9312 \pm 0.0019$ \\
\hline 24 & $0.9699 \pm 0.0005$ & $0.9661 \pm 0.0082$ & $0.9603 \pm 0.0045$ & $0.9323 \pm 0.0020$ \\
\hline 48 & $0.9770 \pm 0.0008$ & $0.9714 \pm 0.0015$ & $0.9625 \pm 0.0009$ & $0.9318 \pm 0.0022$ \\
\hline 72 & $0.9800 \pm 0.0006$ & $0.9734 \pm 0.0002$ & $0.9679 \pm 0.0002$ & $0.9347 \pm 0.0002$ \\
\hline 96 & $0.9829 \pm 0.0004$ & $0.9754 \pm 0.0012$ & $0.9695 \pm 0.0003$ & $0.9370 \pm 0.0012$ \\
\hline 120 & $0.9841 \pm 0.0003$ & $0.9771 \pm 0.0015$ & $0.9702 \pm 0.0003$ & $0.9388 \pm 0.0010$ \\
\hline 144 & $0.9872 \pm 0.0010$ & $0.9782 \pm 0.0032$ & $0.9711 \pm 0.0002$ & $0.9444 \pm 0.0042$ \\
\hline 168 & $0.9877 \pm 0.0003$ & $0.9840 \pm 0.0034$ & $0.9736 \pm 0.0020$ & $0.9431 \pm 0.0005$ \\
\hline 192 & $0.9871 \pm 0.0004$ & $0.9839 \pm 0.0047$ & $0.9728 \pm 0.0002$ & $0.9432 \pm 0.0017$ \\
\hline \%Difference & 6.9 & 5.9 & 3.8 & 3.0 \\
\hline
\end{tabular}

$\%$ Difference $=\frac{\left(v_{f}-v_{i}\right)}{\frac{\left(v_{f}-v_{i}\right)}{2}}$

where $v_{f}$ and $v_{i}$ are the final and initial viscosity values respectively.

Table A2 Average (average \pm standard deviation): 6 values; 3 measurements for duplicate experiments) viscosity data for all oils weathered on seawater in spring and summer conditions. Viscosity values were measured at $15^{\circ} \mathrm{C}$

\begin{tabular}{llll}
\hline $\begin{array}{l}\text { Sampling Time } \\
\text { (Hours) }\end{array}$ & $\begin{array}{l}\text { AWB } \\
\text { (cSt) }\end{array}$ & $\begin{array}{l}\text { WCS } \\
\text { (cSt) }\end{array}$ & $\begin{array}{l}\text { Synbit } \\
\text { (cSt) }\end{array}$ \\
\hline Weathering Study (Spring) & & & $\begin{array}{l}\text { Heidrun } \\
\text { (cSt) }\end{array}$ \\
0 & $265 \pm 1$ & $260 \pm 1$ & $242 \pm 1$ \\
3 & $3711 \pm 10$ & $1143 \pm 40$ & $632 \pm 10$ \\
8 & $6110 \pm 10$ & $1570 \pm 20$ & $911 \pm 10$ \\
24 & $13510 \pm 140$ & $4057 \pm 50$ & $1478 \pm 30$ \\
48 & $21625 \pm 330$ & $5267 \pm 60$ & $2393 \pm 20$ \\
72 & $27083 \pm 330$ & $7498 \pm 60$ & $2598 \pm 60$ \\
96 & $26563 \pm 890$ & $7280 \pm 80$ & $3059 \pm 60$ \\
120 & $33085 \pm 220$ & $8085 \pm 200$ & $3795 \pm 110$ \\
144 & $32447 \pm 1800$ & $9388 \pm 30$ & $4168 \pm 80$ \\
168 & $36268 \pm 720$ & $11838 \pm 220$ & $4385 \pm 40$ \\
\hline
\end{tabular}

https://doi.org/10.30799/jespr.176.19050305

Cite this Article as: Thomas King, Patrick Toole, Brian Robinson, Scott Ryan, Kenneth Lee, Michel Boufadel, Haoshuai Li, Jason Clyburne, Influence of climatic parameters on changes in the density and viscosity of diluted bitumen after a spill, J. Env. Sci. Pollut. Res. 5(3) (2019) 373-382. 


\begin{tabular}{llll}
\hline $\begin{array}{l}\text { \%Difference } \\
\text { Weathering Study (Summer) }\end{array}$ & $36439 \pm 1600$ & $11444 \pm 40$ & $4568 \pm 50$ \\
0 & 197 & 191 & 180 \\
0 & $299 \pm 1$ & $308 \pm 5$ & $242 \pm 3$ \\
3 & $2071 \pm 20$ & $2330 \pm 70$ & $776 \pm 5$ \\
8 & $6074 \pm 40$ & $3867 \pm 90$ & $1113 \pm 4$ \\
24 & $11970 \pm 60$ & $4980 \pm 50$ & $1939 \pm 20$ \\
48 & $20102 \pm 340$ & $8090 \pm 150$ & $3202 \pm 40$ \\
72 & $25054 \pm 650$ & $10600 \pm 80$ & $4472 \pm 110$ \\
96 & $36610 \pm 2100$ & $12956 \pm 450$ & $5694 \pm 80$ \\
120 & $45679 \pm 940$ & $15712 \pm 1200$ & $6525 \pm 90$ \\
144 & $56079 \pm 2100$ & $20201 \pm 1500$ & $7603 \pm 40$ \\
168 & $66246 \pm 1700$ & $24201 \pm 2100$ & $10195 \pm 240$ \\
192 & $69309 \pm 1700$ & $25073 \pm 1200$ & $10924 \pm 0$ \\
\%Difference & 198 & 195 & $253 \pm 5$ \\
\end{tabular}

Table A3 Multiple correlation analysis of parameters of climate and density and viscosity of AWB weathered on water in spring and summer. Values in the table are Pearson Coefficient of Determination ( $r$ ). When ' $r$ ' is positive change in the dependent variables (density and viscosity) increase with an increase in the values of the independent variables (air and water temperature, wind speed, and sunlight energy). A negative ' $r$ ' indicates increasing change in the dependent variable with a decreasing change in the independent variables. Regression Analysis is reported for significant relationships in Tables A7 (density) and A8 (viscosity) for values highlighted in grey. Temperature (Temp).

\begin{tabular}{|c|c|c|c|c|c|}
\hline & Air Temp & Water Temp & Wind speed & Light Intensity & density \\
\hline \multicolumn{6}{|l|}{ AWB Spring } \\
\hline Air Temp & 1 & & & & \\
\hline Water Temp & -0.50 & 1 & & & \\
\hline Wind speed & 0.24 & 0.13 & 1 & & \\
\hline Light Intensity & -0.17 & 0.63 & -0.07 & 1 & \\
\hline density & 0.40 & -0.74 & 0.15 & -0.92 & 1 \\
\hline \multicolumn{6}{|l|}{$\underline{\text { AWB Summer }}$} \\
\hline Air Temp & 1 & & & & \\
\hline Water Temp & -0.75 & 1 & & & \\
\hline Wind speed & 0.43 & -0.21 & 1 & & \\
\hline Light Intensity & 0.73 & -0.42 & 0.68 & 1 & \\
\hline density & -0.40 & 0.21 & -0.77 & -0.86 & 1 \\
\hline \multicolumn{6}{|l|}{$\underline{A W B \text { Spring }}$} \\
\hline Air Tem & 1 & & & & \\
\hline Water Tem & -0.48 & 1 & & & \\
\hline Wind Speed & 0.31 & -0.03 & 1 & & \\
\hline Light Intensity & -0.16 & 0.81 & 0.00 & 1 & \\
\hline Viscosity & 0.63 & -0.88 & 0.33 & -0.78 & 1 \\
\hline \multicolumn{6}{|l|}{$\underline{\text { AWB Summer }}$} \\
\hline Air Tem & 1 & & & & \\
\hline Water Tem & -0.56 & 1 & & & \\
\hline Wind Speed & 0.03 & 0.08 & 1 & & \\
\hline Light Intensity & 0.31 & 0.51 & 0.31 & 1 & \\
\hline Viscosity & 0.86 & -0.44 & -0.66 & 0.31 & 1 \\
\hline
\end{tabular}

Table A4 Multiple correlation analysis of parameters of climate and density and viscosity of WCS weathered on water in spring and summer. Values in the table are Pearson Coefficient of Determination (r). Regression Analysis is reported for significant relationships in Tables A7 (density) and A8 (viscosity) for values highlighted in grey. Temperature (Temp).

\begin{tabular}{|c|c|c|c|c|c|}
\hline & Air Temp & Water Temp & Wind speed & Light Intensity & density \\
\hline \multicolumn{6}{|l|}{ WCS Spring } \\
\hline Air Temp & 1 & & & & \\
\hline Water Temp & 0.27 & 1 & & & \\
\hline Wind speed & -0.10 & -0.56 & 1 & & \\
\hline Light Intensity & 0.14 & 0.80 & -0.51 & 1 & \\
\hline density & -0.08 & -0.84 & 0.53 & -0.85 & 1 \\
\hline \multicolumn{6}{|l|}{$\underline{\text { WCS Summer }}$} \\
\hline Air Temp & 1 & & & & \\
\hline Water Temp & -0.12 & 1 & & & \\
\hline Wind speed & -0.30 & 0.10 & 1 & & \\
\hline Light Intensity & 0.21 & 0.17 & -0.10 & 1 & \\
\hline density & 0.61 & -0.05 & 0.50 & -0.20 & 1 \\
\hline \multicolumn{6}{|l|}{ WCS Spring } \\
\hline Air Temp & 1 & & & & \\
\hline Water Temp & -0.19 & 1 & & & \\
\hline Wind speed & 0.20 & 0.06 & 1 & & \\
\hline Light Intensity & 0.59 & 0.29 & 0.11 & 1 & \\
\hline Viscosity & 0.67 & -0.26 & 0.19 & 0.64 & 1 \\
\hline \multicolumn{6}{|l|}{ WCS Summer } \\
\hline Air Temp & 1 & & & & \\
\hline Water Temp & 0.35 & 1 & & & \\
\hline Wind speed & -0.19 & -0.53 & 1 & & \\
\hline Light Intensity & 0.21 & 0.78 & -0.49 & 1 & \\
\hline Viscosity & -0.02 & -0.83 & 0.37 & -0.74 & 1 \\
\hline
\end{tabular}


Table A5 Multiple correlation analysis of parameters of climate and density and viscosity of synbit weathered on water in spring and summer. Values in the table are Pearson Coefficient of Determination (r). Regression Analysis is reported for significant relationships in Tables A7 (density) and A8 (viscosity) for values highlighted in grey. Temperature (Temp).

\begin{tabular}{|c|c|c|c|c|c|}
\hline & Air Temp & Water Temp & Wind speed & Light Intensity & density \\
\hline \multicolumn{6}{|l|}{ Synbit Spring } \\
\hline Air Temp & 1 & & & & \\
\hline Water Temp & -0.21 & 1 & & & \\
\hline Wind speed & 0.06 & -0.34 & 1 & & \\
\hline Light Intensity & -0.13 & 0.57 & -0.71 & 1 & \\
\hline density & 0.10 & -0.39 & 0.87 & -0.88 & 1 \\
\hline \multicolumn{6}{|l|}{ Synbit Summer } \\
\hline Air Temp & 1 & & & & \\
\hline Water Temp & -0.49 & 1 & & & \\
\hline Wind speed & 0.05 & -0.25 & 1 & & \\
\hline Light Intensity & -0.04 & 0.00 & -0.28 & 1 & \\
\hline density & 0.04 & 0.08 & -0.27 & 0.96 & 1 \\
\hline \multicolumn{6}{|l|}{ Synbit Spring } \\
\hline Air Temp & 1 & & & & \\
\hline Water Temp & -0.21 & 1 & & & \\
\hline Wind speed & 0.05 & -0.20 & 1 & & \\
\hline Light Intensity & -0.21 & 0.71 & -0.42 & 1 & \\
\hline viscosity & 0.12 & -0.11 & 0.79 & -0.82 & 1 \\
\hline \multicolumn{6}{|l|}{ Synbit Summer } \\
\hline Air Temp & 1 & & & & \\
\hline Water Temp & 0.52 & 1 & & & \\
\hline Wind speed & 0.44 & 0.12 & 1 & & \\
\hline Light Intensity & -0.03 & 0.07 & -0.24 & 1 & \\
\hline viscosity & 0.42 & 0.44 & 0.09 & 0.81 & 1 \\
\hline
\end{tabular}

Table A6 Multiple correlation analysis of parameters of climate and density and viscosity of heidrun weathered on water in spring and summer. Values in the table are Pearson Coefficient of Determination (r). Regression Analysis is reported for significant relationships in Tables A7 (density) and A8 (viscosity) for values highlighted in grey. Temperature (Temp).

\begin{tabular}{|c|c|c|c|c|c|}
\hline & Air Temp & Water Temp & Wind speed & Light Intensity & Density \\
\hline \multicolumn{6}{|l|}{ Heidrun Spring } \\
\hline Air Temp & 1 & & & & \\
\hline Water Temp & 0.64 & 1 & & & \\
\hline Wind speed & -0.05 & -0.20 & 1 & & \\
\hline Light Intensity & 0.11 & 0.66 & -0.37 & 1 & \\
\hline density & 0.02 & -0.39 & 0.30 & -0.92 & 1 \\
\hline \multicolumn{6}{|l|}{ Heidrun Summer } \\
\hline Air Temp & 1 & & & & \\
\hline Water Temp & -0.15 & 1 & & & \\
\hline Wind speed & 0.30 & -0.76 & 1 & & \\
\hline Light Intensity & -0.01 & 0.22 & 0.04 & 1 & \\
\hline density & -0.13 & -0.23 & 0.37 & -0.69 & 1 \\
\hline \multicolumn{6}{|l|}{ Heidrun Spring } \\
\hline Air Temp & 1 & & & & \\
\hline Water Temp & 0.64 & 1 & & & \\
\hline Wind speed & -0.05 & -0.20 & 1 & & \\
\hline Light Intensity & 0.11 & 0.66 & -0.37 & 1 & \\
\hline Viscosity & -0.22 & -0.58 & 0.33 & -0.94 & 1 \\
\hline \multicolumn{6}{|l|}{ Heidrun Summer } \\
\hline Air Temp & 1 & & & & \\
\hline Water Temp & -0.39 & 1 & & & \\
\hline Wind speed & 0.37 & -0.79 & 1 & & \\
\hline Light Intensity & 0.43 & 0.06 & 0.34 & 1 & \\
\hline Viscosity & -0.67 & 0.05 & -0.30 & -0.87 & 1 \\
\hline
\end{tabular}

Table A7 Regression analysis of the correlations (Excel- for additional information see Tables A3 to A6) of parameters of climate with density of oil weathered on water in spring and summer. Temperature-Temp, set of $\mathrm{n}$-data points, $\mathrm{R}^{2}$-R squared is the coefficient of determination, $S E$-Standard Error, $M S E$-Mean Square Error, $p$-value $<0.05$ is significant.

\begin{tabular}{|c|c|c|c|c|c|c|c|}
\hline \multirow{2}{*}{ Oil Type } & \multirow{2}{*}{$\begin{array}{l}\text { Climatic } \\
\text { Variable }\end{array}$} & \multicolumn{3}{|c|}{ Regression } & \multicolumn{3}{|c|}{ ANOVA (model fit) } \\
\hline & & $\mathrm{n}$ & $\mathrm{R}^{2}$ & SE & $M S E$ & $p$-value & Significant \\
\hline \multirow[t]{6}{*}{$\overline{\mathrm{AWB}}$} & Spring-Time & & & & & & \\
\hline & Sunlight & 10 & 0.92 & $4.3 \mathrm{E}+03$ & $7.8 \mathrm{E}+08$ & 0.0002 & $<0.05$ \\
\hline & Water Temp & 10 & 0.74 & 1.3 & 56 & 0.0005 & $<0.05$ \\
\hline & Summer-Time & & & & & & \\
\hline & Sunlight & 10 & 0.86 & $4.9 \mathrm{E}+03$ & $5.4 \mathrm{E}+08$ & 0.001 & $<0.05$ \\
\hline & Wind Spd & 10 & 0.77 & 1.7 & 98 & 0.0006 & $<0.05$ \\
\hline \multirow[t]{5}{*}{ WCS } & Spring-Time & & & & & & \\
\hline & Water Temp & 10 & 0.84 & 2.4 & $1.1 \mathrm{E}+02$ & 0.002 & $<0.05$ \\
\hline & Light & 10 & 0.85 & $1.0 \mathrm{E}+04$ & $2.9 \mathrm{E}+09$ & 0.002 & $<0.05$ \\
\hline & Summer-Time & & & & & & \\
\hline & Air Temp & 10 & 0.61 & 0.04 & $8.6 \mathrm{E}-04$ & 0.04 & $<0.05$ \\
\hline \multirow[t]{5}{*}{ Synbit } & Spring-Time & & & & & & \\
\hline & Sunlight & 10 & 0.88 & $5.5 \mathrm{E}+03$ & $8.3 \mathrm{E}+08$ & 0.0005 & $<0.05$ \\
\hline & Wind Spd & 10 & 0.87 & 3.9 & $3.7 \mathrm{E}+02$ & 0.001 & $<0.05$ \\
\hline & Summer-Time & & & & & & \\
\hline & Sunlight & 10 & 0.96 & $9.3 \mathrm{E}-04$ & $1.4 \mathrm{E}-04$ & 0.0001 & $<0.05$ \\
\hline
\end{tabular}




\begin{tabular}{llccccc}
\hline Heidrun & $\begin{array}{l}\text { Spring-Time } \\
\text { Sunlight }\end{array}$ & 10 & 0.92 & $2.2 \mathrm{E}+03$ & $1.7 \mathrm{E}+08$ & 0.001 \\
$\begin{array}{l}\text { Summer-Time } \\
\text { Sunlight }\end{array}$ & 10 & 0.69 & $9.2 \mathrm{E}+05$ & $2.2 \mathrm{E}+09$ & 0.05 \\
\hline
\end{tabular}

Table A8 Regression analysis of the correlations (Excel- for additional information see Tables A3 to A6) of parameters of climate with the viscosity of oil weathered on water in spring and summer. Temperature-Temp, set of n-data points, $\mathrm{R}^{2}$-R squared is the coefficient of determination, $S E$-Standard Error, $M S E$-Mean Square Error, $p$-value $<0.05$ is significant.

\begin{tabular}{|c|c|c|c|c|c|c|c|}
\hline \multirow{2}{*}{ Oil Type } & \multirow{2}{*}{$\begin{array}{l}\text { Climatic } \\
\text { Variable }\end{array}$} & \multicolumn{3}{|c|}{ Regression } & \multicolumn{3}{|c|}{ ANOVA (model fit) } \\
\hline & & $\mathrm{n}$ & $\mathrm{R}^{2}$ & SE & $M S E$ & $p$-value & Significant \\
\hline \multirow[t]{5}{*}{$\overline{\mathrm{AWB}}$} & Spring-Time & & & & & & \\
\hline & Sunlight & 10 & 0.79 & 5700 & $6.4 \mathrm{E}+08$ & 0.004 & $<0.05$ \\
\hline & $\begin{array}{l}\text { Water Temp } \\
\text { Summer-Time }\end{array}$ & 10 & 0.88 & 1.5 & 52 & 0.002 & $<0.05$ \\
\hline & Air Temp & 10 & 0.86 & 1.1 & 29 & 0.006 & $<0.05$ \\
\hline & Wind Speed & 10 & 0.86 & 2.1 & 101 & 0.001 & $<0.05$ \\
\hline \multirow[t]{6}{*}{ WCS } & Spring-Time & & & & & & \\
\hline & Sunlight & 10 & 0.64 & $1.5 \mathrm{E}+03$ & $2.9 \mathrm{E}+07$ & 0.04 & $<0.05$ \\
\hline & Air Temp & 10 & 0.67 & 0.32 & 1.4 & 0.03 & $<0.05$ \\
\hline & Summer-Time & & & & & & \\
\hline & Water Temp & 10 & 0.83 & 1.8 & 94 & 0.01 & $<0.05$ \\
\hline & Sunlight & 10 & 0.74 & $1.1 \mathrm{E}+04$ & $1.9 \mathrm{E}+09$ & 0.04 & $<0.05$ \\
\hline \multirow[t]{4}{*}{ Synbit } & Spring-Time & & & & & & \\
\hline & Sunlight & 10 & 0.82 & $1.5 \mathrm{E}+03$ & $2.0 \mathrm{E}+07$ & 0.01 & $<0.05$ \\
\hline & $\begin{array}{l}\text { Wind Speed } \\
\text { Summer-Time }\end{array}$ & 10 & 0.79 & 3.0 & $1.9 \mathrm{E}+02$ & 0.01 & $<0.05$ \\
\hline & Sunlight & 10 & 0.81 & $1.6 \mathrm{E}+03$ & $1.1 \mathrm{E}+08$ & 0.008 & $<0.05$ \\
\hline \multirow[t]{4}{*}{ Heidrun } & Spring-Time & & & & & & \\
\hline & Sunlight & 10 & 0.93 & $2.2 \mathrm{E}+03$ & $1.7 \mathrm{E}+08$ & 0.0006 & $<0.05$ \\
\hline & Summer-Time & & & & & & \\
\hline & Sunlight & 10 & 0.87 & $165 \mathrm{E}+04$ & $4.3 \mathrm{E}+09$ & 0.005 & $<0.05$ \\
\hline
\end{tabular}

